\title{
Parenting Style and Its Implication to Children's Education
}

\author{
(A Study on Dayak People in Halong, Balangan District)
}

\author{
Rabiatul Adawiah \\ Teacher Training and Education Faculty \\ Universitas Lambung Mangkurat \\ Banjarmasin, Indonesia
}

\begin{abstract}
The Constitution states that everyone has the right to attain the highest level of education without exception. However, there are still many children who have dropped out of school, including the Dayak community in Balangan district. This problem certainly needs to receive attention from all parties. If this problem is ignored, there is a possibility that children in the remote areas such as Dayak people in Balangan Regency will always be lagging. Children who dropped out or even do not attend school is thought to be closely related to parents' understanding of education, including the understanding of the applied educational styles. Therefore, the education styles of Dayak children in Balangan regency needs to be deeply studied. The objectives of this research are to know: (1) parents understanding about children's education, (2) styles applied by parents in children's education, and (3) factors influencing children's education styles of Dayak people in Balangan Regency. Data collection was done by interview and documentation techniques. The data obtained were analyzed descriptive qualitative. The results of this study indicate that the understanding of Dayak parents in Halong sub-district is categorized as good. They generally understand that education is very important. This can be seen from the answers of all informants who said that basically, they want their children to go to school as high as possible. The education styles applied by most Dayak people are permissive parenting and democratic styles. Factors affecting the children's education styles are (1) family social-economic level, (2) parent's education level, (3) distance between school and residence, (4) age, and (5) number of children.
\end{abstract}

\section{Keywords-parenting styles, education, Dayak people}

\section{INTRODUCTION}

Being a developed nation is certainly a purpose that wants to be achieved by every country in the world. In fact, people have shared the same understanding that a country status as a developed one can be affected by its education. Education itself is highly important that a nation is considered as advanced or not can be generally seen from education. If the output of this educational process fails, it is hard to imagine how a nation can make a progress. For a nation that wants to move forward, education must be viewed as a necessity as well as other needs. In education itself, there are many things that we can obtain. As stated by Daoed Joesoef [1]"Education is all livelihoods, in choosing and fostering a good life, in accordance with human dignity". From the statement, we can conclude that education is very important and cannot be separated from people's life.

Education is a very important thing, yet there are still many people in Indonesia who does not receive education properly, for instance, the children in Balangan District. The results of the 2012 survey that was conducted in three sub-districts of Paringin, South Paringin, and Halong showed that 32 students did not go to school or dropped out (only to elementary school). One of the reasons was because they have to work [2]. Balangan district, in fact, has a diverse community of ethnic, religious, cultural and other backgrounds. One of them is the Dayak tribe. Dayak people in Balangan district spread in Halong and Tabing Tinggi sub-district, they are commonly called as Dayak Meratus or Bukit. Dayak tribe in Balangan Regency is located in hilly and mountainous areas, causing access to education facilities to be difficult and isolated and remote areas. Education Level of Dayak people in Balangan district is still low. This happens in many ways, among others, geographical location, customs, culture, population distribution, and so on.

The Constitution states that everyone has the right to attain the highest education without exception, including Dayak people living in remote areas. However, there are still many children who dropped out of school, including the Dayak people in Balangan district. This problem should receive the attention of all parties. If this problem is ignored, there is the possibility that children in the remote areas such as Dayak people in Balangan Regency will always be lagging. Children who dropped out or even do not attend school is thought to be closely related to parents' understanding of education, including the understanding of the applied educational styles. Therefore, the education styles of Dayak children in Balangan regency needs to be deeply studied.

In order to address the abovementioned issue, the objectives of this research are to know: (1) parents understanding about children's education, (2) styles 
applied by parents in children's education, and (3) factors influencing children's education styles of Dayak people in Balangan Regency. Data collection of this study was done by interview and documentation techniques. Meanwhile, the data obtained were analyzed descriptive qualitative. The results of this study can be used as a reference/ guidance for the stakeholders in the education field in order to develop human beings who knowledgeable, able to build and master technology, highly competitive, and have faith and devotion to God Almighty, or become the direction of policy and education implementation plan in Balangan district.

\section{METHOD}

The place of the study is Halong, Balangan district. Halong sub-district was chosen as the place of the study because the number of Dayak people in this subdistrict is higher than the other district. Qualitative method was used in this study because data (information) searched or collected were qualitative. Qualitative research in addition to revealing and describing real events in the field can also reveal the hidden values of this research. In addition, this research is also sensitive to descriptive information and trying to maintain the integrity of the object under study. In this study, the researcher is in the position as the key instrument [3]

In accordance with the data source selected, the type of data in this study was words or stories directly from the research informants, actions or patterns of parents thought about the education of their children and data related to education. Descriptions in the form of words or stories directly from informants were used as the primary data, while the writing or data from various documents serve as secondary data.

In this qualitative research, the researcher acted as the main instrument that went to the field and collected the information through observation and interview. The interviews were open and unstructured. To facilitate the collection of data, the researcher used tools such as field notes, tape recorders, photo cameras and interview guides. This research uses an interactive model of analysis technique [4] in this interactive analysis model; the researcher moved on three components namely data reduction, data display, and verification.

\section{RESUlt AND Discussion}

\section{A. Parents' Understanding About Children's Education}

Education is a human effort to nurture his/her personality to conform the norms or rules of the society. Every adult in society can become an educator, for an educator is a fundamental social act for the children's growth or development into human beings who are capable of thinking maturely and wisely. Although most parents in Halong sub-district are poorly educated, they are generally well aware that education for their children is actually very important. This was revealed from the statement of one of the informants, Mr. Rusdiames. Rusdiames is a 34-yearold man who has two children. He said that he only attended elementary school. His wife, Sariadah, 31 years old, only went to elementary school. He is a farmer, and to the researcher, he said that: "I think that child's education is very important. Children's education should be more advanced than their parents. Do not be like us who only go until elementary school, and children should not drop out of school. We are trying to find the cost."

Although Rusdiames and his wife pursued elementary school education only, they are very interested in the importance of education. Both of his children remain in school. A similar statement was stated by another informant, Kutie. Kutie is also a 40year-old man as the head of the family. His daily job is as a rubber tapper. In relation to his children's educational problem, to the researcher, he said: "our son should not be like us who never go to school. Our son is free to go where he wants to go, and we also tell him to go to school. Mr. Kutie has never actually received an education, nor has his wife Sakau. Nevertheless, he understands enough about the importance of education for his children. He tries as hard as possible for his children to continue school. This can be seen from his two children, no one dropped out of school, even one of them go to a school which in other districts namely Hulu Sungai Tengah (SMA Barabai).

Another similar statement was made by another informant, Yamani, who is 30 years old and has two children. Yamani solely graduated from elementary school as well as his wife, Mariwiyah. Two of his children, one kid is attending elementary school and the other one is not yet in school. To the researcher he said that "my children will be able to go to college, keep going to school and will not drop out school". Not much different from the previous informant, Rusdi, another informant, also highly understands the importance of education. Rusdi is one of the heads of the family with three children and his daily work is as a rubber farmer. Mr. Rusdi has never attended a school nor has his wife Rusinah. Even when he was asked about his age, he did not know how old he was. Nevertheless, he is expecting his children to go to school. To the researcher he said: "I hope all the children can go to school. However, since there is no money only our first child can continue school. Our second and third children only go to Elementary School and no longer continue their education. I want them to go to school, but how if there is no cost?"

Another opinion was stated by Ilik who is 60 years old. Ilik has never gone to school as well as his wife, Layun, 55 years old. Mr. Ilik also works as a rubber tapper and has three children. All his children are not dropped out of school and some even go to college. Mr. Ilik said that "We send the children to schools according to their respective talents. All of our children 
go to school, the first one was graduated from high school, the second one was also graduated from high school and continues the college and the third is still in elementary school. Our job is only looking for the money."

A similar statement was also made by Mr. Acin, a 67-year-old informant. Mr. Acin never attended school, as did his wife Sanah, 50 years old. Mr. Acin has two children. Regarding the education of his children, he stated that: "we know that school is important, but what if we do not have any money. So our boys work to help us." From the explanation of Mr. Acin can be revealed that in fact, he wanted to send his children to school, but his economic condition makes it impossible; then, he is reluctant to ask his children to work in the garden as a rubber tapper. What has been done by Mr. Acin is in accordance with what is stated [5] that the economic situation closely related to the education of children. If the child lives in a poor family then the basic needs of children is not fullfilled, and the educational needs is also not fullfilled, causing the child to leave his education.

Salim [5] states that in general, family incomes of children from poor family are only used to fulfill the primary needs, especially for food purposes, while other purposes are not considered important. Sunarto [5] also said that parents with low economic backgrounds would expect more help from their children than high social economic parents. Thus, with the consequences of such situation, the learning process is disrupted since the child's learning time is taken to help parents. A similar statement is also stated [6] that poverty is a deficiencies situation that the occurrence was not desired by the poor generally characterized by low levels of education, work productivity, income, health, nutrition, and welfare thus showing a circle of helplessness. Furthermore, it is said that poverty is caused by limited human resources owned and utilized especially from the level of formal and non-formal education and bring consequences to low informal education.

Another statement was made by Mr. Imis, a 65year-old informant. Mr. Imis works as a rubber tapper and has never gone to school. Similarly, his wife Masitah who was 50 years old has never gone to school. They admit that education is very important for their children. However, due to the limited cost, only one child can reach high school but cannot graduate from the school. In relation to educational issues to researcher, Mr. Imis further said that "we think education is important, but we do not have any money to send our children away, it is better to help us farming here."

What was said by Mr. Imis is in accordance with the statement expressed [7] who says that the weakness of people's economic condition is one of the causes of the occurrence of school drop out. If the economic condition of parents is low, then the needs of children in education can not be fulfill properly. On the contrary, a sufficient need for children is based on the economic ability of the parents, which can fulfill all the needs of children's interests, especially in the field of education. Furthermore, Baharuddin also says that: "It seems that in our country the funding factor is the main obstacle, to catch up our lagging in the world of education. It is undeniable that without sufficient funds, perfect education can not be achieved.

It is undeniable that the distance also the causes the children school drop out. From the explanation of Mr. Imis, it can be seen that he sees education as highly important. As he has a limited fund, he can only send his children to high school, yet cannot graduate because the cost is not possible anymore. Continuing to high school is not easy for Mr. Imis who lives in the Mentayan village because there is no senior high school available in his village. In order to send their children to senior high school level, they have to go to the district capital or because they consider it is nearer than the district capital they have to send them to Barabai.

The results of this study are in accordance with a research conducted [8] who says that the lack of transportation facilities that can transport children to school is one of the factors that cause the children to drop out of school. Although the government has budgeted for free education through school operational assistance (BOS), but of course it has not able to help the cost of children education as a whole.

As Mustika, an informant who has been teaching in the Halong sub-district said: "Children who go to school generally are asked to go to the garden for tapping rubber trees by their parents in the afternoon, and the money is usually for the children. Generally, those who can earn money which is between IDR 100.000 to 200.000 per week they think that if they stay in school they will not earn that much money, and eventually they tend to work more than continue school. That is one of the reasons why children in many remote areas drop out of school." Futhermore, because of economic reasons, some parents in subdistrict marry off their children early, especially women. It is not even a rare case that some of them marry off their children at a very young age (under 16 years). As one informant, Puli who said that: "Many of the children did not go to school because they were married. Usually, if a child can hold a knife to tap rubber, and then there is someone who proposes, the child will get married."

From some informants that were interviewed, a conclusion can be drawn that Dayak people in Halong sub-district generally have already understood how important education for children, both for parents who are young or old, for those who have little children and for parents who have many children, and also for those who have never received an education or for those who have been educated. 


\section{B. Education Styles Applied by Parents in Children's Education}

Every parent always wants the best for their children. This feeling then encourages parents to have certain behaviors in caring for their children. This research revealed some education styles applied by parents (Dayak people) in sub-district of Halong, which are:

\section{1) Permissive Parenting}

It is known that permissive parenting is a parenting style which the parents give full freedom to the child to make decisions and do it and also never give explanation or direction to the child. The application of permissive parenting style can be seen from some of the informants' answers to the researcher. One informant named Kayau, 55 years old, who has never attended school told the researcher that: "I have told the children to go to school, but because we start to work in the garden at dawn, we cannot tell whether the children were really in school or not. But it looks like they were in school." Similar statement was also raised by one of the respondents, Ilik, who explained to the researcher that: "On the children education, I handed it over to the child, it is up to him whether he wanted to go to school or not, if he does not want to attend school, I will not force the child. We force the child to attend school if he does not want to go to school."

What the informants said above is in accordance with what is proposed by Baumrin [9] who said that permissive family parenting does not provide the proper structure and boundaries for their children. Permissive parenting is a form of parenting where parents give as much freedom as possible to the children to manage themselves. Children are not required to be responsible and not controlled by parents. Furthermore, it is said that permissive parenting views a child as a person and encourages them to be undisciplined and the child is allowed to manage his/her own behavior. With this kind of parenting, the children get as much freedom as possible from his family. Parents tend to not admonish or warn their children when they are in danger, and very little guidance is given by the parents. As one informant named Puli said: "Because most parents spend all day long tapping rubber, thus they cannot watch their children. They go at dawn and come back in late afternoon." The statement from Puli also suggests that parents generally pay less attention to the education of their children and do not care whether the children go to school or not.

Implementation of permissive parenting style or known as the all-out parenting is a parenting where the parents are reluctant, obeying all wishes, protecting excessively and giving or fulfilling all the children's wishes. However, this type of parents is usually warm; thus, they are often liked by children. Permissive parenting pattern contains a relationship between children and parents which filled with affection, but it makes the children become aggressive and have a tendency to follow their conscience. Broadly, the parents' weaknesses and inconsistencies in the discipline applied to make the children uncontrollable, disobedient, and aggressive outside the family environment.

This parenting style makes teenagers spend more time outsides with friends. Permissive parents are rigid parents and focus on their own needs. Especially as children become older, parents fail to watch them, what they are doing or who their friends are. In addition to interviewing parents, the researcher also conducted interviews with teachers in Halong sub-district. One of the teachers is Mustika who said that: "On the children education, generally parents give freedom to the child. If the child wants to go to school the parents will support him/her, but if the child does not want to go to school the parents also do not force the child. Mustika also said that "the average parents work all day outdoors (as a rubber tapper). It is rather difficult to provide guidance and supervision to the child if they work all day outdoors. Those parents usually do not really care about their children's education, because they are preoccupied with the activities to earn living for the family.

Permissive parenting style can be interpreted as a parenting style which in interacting with children, parents let the children do what they want to do without questioning. This parenting style does not use strict rules and even less guidance given, so there is no control and demand to the children. Freedom is given fully and the children are allowed to decide for themselves, without parental consideration and behave according to what they want without any parental control. With this, the children try to learn by themselves about how to behave in social environment.

In this permissive (all-out) parenting style, parents are not controlling and less demanding. They are not well-organized or ineffective in running the household, weak in disciplining and teaching children, only demand a little adulthood and give less attention to train self-reliance and self-confidence. Parents with permissive parenting are allowed to regulate their own behavior and make their own decisions. [10] as notes that permissive parenting does not use strict rules and even guidance is rarely given so there is no control and demands on the children. Freedom is given fully and children are allowed to make decisions for them without parental consideration and may behave according to what they desire without any parental control. Baumrind [9] describes two types of permissive families: soft, permissive (spoiling) and irresponsible family (uncaring).

\section{2) Democratic Parenting}

In addition to the illustration of permissive parenting style, the education style depicted in the Dayak people in Halong sub-district is democratic parenting. This is revealed from the results of interviews with some research informants. As what has been pointed out that parents who are categorized as democratic are those who try to direct their children to 
behave in a rational manner by giving a prior explanation to the children. Parents give an explanation about the demands and discipline applied, but they still keep their authority or give punishment if it is necessary. Parents impose a series of standards and rules that are applied seriously and consistently. Democratic parents use high control with high warmth.

One of the informants, Mustika, told the researcher that: "there are also parents who require their children to keep going to school. However, usually such parents are educated too, like the headman whose children are all educated, because he is also educated." Another informant was Rusdi who actually allows his children to continue school. One of his three children, the first one continues school until high school although it is in the other district which is Hulu Sungai Tengah district. This means that he frees his children to continue their education to a higher level. Not much different from the previous opinion, another informant named Poli who worked as a civil servant said: "I do not think children should drop out of school let alone not going to school. I expect the children to continue their education as high as possible and do not drop out in the process. Parents will be proud if their children can go to school as high as possible." One of the informants, Ilik, said that: "We think the children should continue schooling, and my children are like that, I send them to schools according to their talents."

From the informant's answer, it can be seen that as a parent he is trying to direct his children to school as high as possible. For that as the parents, they try as hard as possible to find the school funds for their children. These types of parents are rational and always base their actions on logical thinking. They are also realistic about the ability of their children. They do not expect more on their abilities. Democratic parents also give the children the freedom to choose. They also let the children to decide an action. If the children need advice, democratic parents will always do it with a warm approach.

Democratic style of parenting is appropriate at 6-12 years of age. At this stage, children begin to be able to choose what they are interested in. Children are also interested in new things and tend to get bored with something monotonous. More importantly, according to Tika, children begin to understand conceptual issues such as rights and obligations. "The democratic requires parents to give a logical reason for each given rule, thus the parents cannot carelessly tell the children what to do. Democratic style allows children to be free but still responsible.

When comparing both of parenting styles that are applied by the community, the most are those who apply democratic parenting. This is in accordance with the results of research proposed [11] that $51 \%$ of parents apply democratic parenting, $62.7 \%$ of collegeeducated parents, and $90.2 \%$ of parents in middle adult age range. It is revealed that parents with high education prefer the type of democratic parenting and the parents in adulthood are more open, warm, and caring for their children.

According to Muttaqin [11] that democratic parenting can lead to independent, strong self-control and confident children who interact with peers well, able deal with stress, have interest in new things, cooperate with adults, and also are submissive, obedient and achievement-oriented. The results of research also show that the type of democratic parenting is the most parenting pattern applied by parents to their children because democratic parenting has the principle of encouraging children to be independent, but parents still set limits and controls. Parents are usually warm and compassionate to the child, can accept the reason of all child acts and support them.

\section{3) Factors Influencing Children's Education Styles of Dayak People in Balangan District}

Parenting styles are behavior patterns applied to the children and are relatively consistent over time. This pattern of behavior can be felt by the children, in terms of negative and positive. Speaking of how parents in educating their children, of course, this cannot be separated from the understanding and views of parents in educating. Their ways of educating greatly determine the nature of their children's personality.

The results of this study reveal the existences of several factors that affect the children's education style are:

\section{Socioeconomic Status}

Socioeconomic status greatly affects the education styles applied by parents. One of the informants is Imis, 65 years old. Imis said that: "Our two children, both of them go to school. One of them was graduated from elementary school and another one went to high school but did not graduate. There is no money to send the children away, it is better for them to help us farming here. From the informant's statement can be seen that because of economic limitations the children cannot continue their school. A similar statement was made by another informant, Tirus, 50 years old, who has never received any education. His daily work is as a farmer. Tirus explained that: "Because of our economic condition, it is impossible to send children to higher education." Tirus has 10 children. All his children attended school, but no one is graduated from high school. From the informant's statement, it is also revealed that the economic condition is the cause that he cannot send his children to high school.

A similar statement was also stated by Tiron. Tiron is a 60 years old man who works as a farmer. Tiron explained that: "Our children were asked to help the family economy. Just working, they do not go to school. It is better to make money to help their father and mother." What Tiron said is also similar to what Kayau proposed. Kayau is 55 years old informant who has eight children. From eight children, only one succeeded in graduating high school. While others in on average were only graduated from elementary 
school. Then, to the researcher Tiron explained that due to economic factors, all his children almost dropped out of school. Children who have low socioeconomic tend not to continue their education to a higher level or even have never received any education because they were constrained by the economic status.

Unlike the previous case, another informant named Puli is a civil servant (teacher) in Halong sub-district. Puli said: "In the future, the children can continue their education as high as possible." Puli's statement is in accordance with what Mustika said: "if parents have a good economic condition, generally they always send their children to school as high as possible".

From some of the informants' answers can be concluded that if the parents have a middle level of the economy, they are generally more likely to send their children to help them work in the garden. Whereas if the parents are better economically, there is a tendency to keep sending their children to continue school as high as possible. Weak economic condition is one of the causes of school dropout. If the parents' economic condition is underprivileged, then the needs of children in the field of education cannot be full filed properly. On the contrary, a sufficient need for the child is based only on the economic ability of his parents, which can fulfill all the needs of the child's interest, especially in the field of education.

\section{Parents' Education Level}

Another factor that affects the children's education styles is the level of parents' education. Parents' education background can affect the parental mindset in educating their children. As one informant said, Ancun who was graduated from junior high, while his wife only was graduated from elementary school. Ancun only has two children, one of his children currently studies in college. A similar statement was also made by Rusdianus. Rusdianus said: "Children's education must be higher than their parents, not only until elementary school. We will try to find the cost for them." The same thing was also expressed by Mustika who graduated from college. Mustika further said: "If the parents are educated, usually they do not allow their children to go to the garden. So usually they will prioritize the education of their children."

In contrast to parents who have never received any education. As what Mundi has pointed out. Mundi has never received any education, nor has his wife Atung. Mundi said that: "I have four children, and none of them finish elementary school. In my opinion, it is better for the children to help his parents working." A similar statement was also stated by Adun. Adun never went to school, no did his wife Mawar. Adun said: "I think it is better for children to help their parents working as rubber tappers."

From some informants' statements mentioned above, it can be concluded that educated people are more concerned about the education of their children compared with parents who are not educated. This is in line with what is suggested [12] that the educational background of parents can influence the both formal and non-formal parental mindset and also affect the aspirations or expectations of parents to their children.

\section{Distance Between Residence and School}

For Dayak people in Halong sub-district, currently, there are only elementary schools that are available, if they want to continue to higher level, they have to travel that, of course, takes hours if they ride a bike. Dayak people in Halong sub-district said that they feel that it is closer to send their children to Barabai than to the capital of Balangan district. Therefore, from some informants who were interviewed, they said that they send their children to Barabai (HST).

The distance between residences to school also affects parents' mindset about their children's education, especially if the economic condition of the parents is low. As what one of the informants named Layai stated. Layai lived in Urin village, but his residence is far from the Urin village although it still in the area of Urin village. From three children, only one child went to elementary school, while the other two did not attend school. When he was asked why he did not send his son to school, Layai said that "our children were told to work for money; we live far away in the mountains. Going to elementary school is already far away, let alone going to junior high school or senior high school. That is why only one child who attends school but the other two do not."

The results of this study are in accordance with what Burhanuddin [13] suggests that there are at least six factors that cause drop-outs, and one of them is the location or distance of the school.

\section{Number of Children}

Although the family planning program (Keluarga Berencana) has long been recognized by the people of Indonesia, including by Dayak people in Halong subdistrict, there are still many people who have more than three children. The attention of parents to one or two children is very different compared with families who have many children, likewise parents' attention in terms of education, especially if the family is a middle economy family.

In relation to the number of children, one of the informants named Tirus said that: "The number of our children is 10 people. Everyone has attended school, but no one gets to finish until high school because there is no cost to support many children." Another statement was made by Mundi: "All of our children did not finish primary school." Unlike other informants all of Ilik's children attend school. From three children, two graduated from high school, and even one of them continues to collage. Meanwhile, the youngest is still in kindergarten.

The results of this study are in accordance with what is expressed [14] that the number of children in a family will affect the parenting styles applied by parents. The more number of children in the family, then there is a tendency that parents will poorly apply 
the maximum parenting for children because the attention and time are divided between the children.

\section{Parents' Age}

Age of a person also has an effect on the education style applied to their children. Of all the informants interviewed those who less than 50 years old were more concerned with their children's education than those who were older than 50 years old. This is as stated by a 36-year-old informant named Kutie. Kutie has two children, and both of them go to school. Although Kutie and his wife have never been educated, Kutie is determined to send his children to school as high as possible. Even there is no high school in Halong, he sent his son to Barabai High School. To the researcher Kutie said: "Our children should not be like us who do not go to school. The children are free to go to school, as long as they want and we told them to go to school."

Similar statement is also said by Yamani. Yamani is a 30-year-old informant. Although he and his wife only received elementary school education and did not graduated, but they are determined to be able to send their children to college. As what Yamani said: "We want our children to be able to continue their school until graduate school, continue School without dropping out."

However, different statements were stated by informants who are above 50 years. They prefer their children to help the family economy. Just like an informant named Kayau said. Kayau is 55 years old man who has eight children. But he said that his children should be able to help the family economy. Therefore the school is only secondary need.

The same thing was also stated by another informant, Acin. During the interview, Acin was 67 years old. His daily work is farming. To the researcher, Acin said that: "We told our children to work because of the family's troubled economic situation."

\section{Conclusions And Suggestions}

\section{A. Conclusions}

In a nutshell, it can be concluded that:

1. The parent's understanding about the education of Dayak people in Halong sub-district is categorized as good. They generally understand that education is very important. This can be seen from the answers of all informants who stated that basically they want their children to go to school as high as possible.

2. Parenting styles applied by parents to educate the children are namely permissive parenting and democratic parenting styles.
3. Factors affecting children's education styles are (a) family socio-economic status, (b) parent's education level, (c) distance to school, (d) parents' age and (e) number of children.

\section{B. Suggestions}

1. Counseling about education should be done continuously so that the public increasingly understand the importance of education.

2. Relevant institutions should provide educational facilities that are easily accessible by the community (according to SPM of Education).

3. Current access roads to school are poor; this problem needs to get attention from the relevant institutions.

\section{REFERENCES}

[1] Hariyanto, Pentingnya Pendidikan Bagi Kehidupan, (http://belajarpsikologi.com, retrieved from 06 Januari 2012)

[2] I. Hanafi, 32 Pelajar Putus Sekolah, Artikel. (Online) (http://www.antar-kalsel. Retrieved from 9 Pebruari 2013).

[3] Y. S. Lincoln, and F. G. Guba, Naturalistic Inquiry, Beverly, Hill Sage Publication, 1985.

[4] M. B. Miles, \& A. M. Huberman, Analisis Data Kualitatif, terjemahan Tjetjep Rohendi Rohidi, Jakarta: Universitas Indonesia Press, 1992.

[5] Helvivito, Faktor Penyebab Putus Sekolah, (http://helvivito.blogspot.com, retrieved from 3 Januari 2014).

[6] T. Supriatna, Strategi Pembangunan dan Kemiskinan, Jakarta: PT. Rineka Cipta, 2000.

[7] M. Baharuddin, Putus Sekolah dan Masalah Penanggulangannya, Jakarta: Yayasan Kesejahteraan Keluarga Pemuda 66.

[8] Suparyanto, Konsep Pola Asuh Anak, http://dr-suparyanto. blogspot.co.id/2010/07/konsep-pola-asuh-anak.html, retrieved from 5 january 2012.

[9] P. H. Mussen, Pengembangan dan Kepribadian Anak, Jakarta: Arcan, 1989.

[10] E. B. Hurlock, Child Development Jilid II, terjemahan Tjandrasa, Jakarta: Erlangga, 1999

[11] I. Fadillah, "Hubungan Tipe Pola Asuh Orang Tua dengan Emotional Quotient pada Anak Usia Prasekolah di TK Islam Al-Fatihah Sumampir Purwokwrto Utara”, Jurnal Keperawatan Soedirman (The Soedirman Journal of Nursing), Volume 5, No.1, Maret 2010.

[12] A. P. Saputro, Faktor-faktor Penyebab, Anak Usia Sekolah, Pendidikan Dasar, (http://lib.unnes.ac.id/855/, retrieved from 27 Desember 2013), 2011.

[13] N. A. K. Dewi, “Analisis Faktor-Faktor Penyebab Anak Putus Sekolah Usia Pendidikan Dasar di Kecamatan Gerokgak Tahun 2012/2013", Jurnal J urusan Pendidikan Ekonomi Universitas Pendidikan Ganesha Singaraja, Indonesia V o $14, \mathrm{~N}$ o $1,2014$.

[14] M. Tufaila, S. Alam, “ Karakteristik Tanah dan Evaluasi Lahan Untuk Pengembangan Tanaman Padi Sawah di Kecamatan Oheo Kabupaten Konawe Utara", AGRIPLUS, Vol. 24, No. 2, 2014. 